\title{
Impact of Effective Internal Control in the Management of Mother and Child Hospital Akure, Ondo State
}

\author{
Adebiyi Ifeoluwa Mary \\ Internal Audit Unit, Vice Chancellor's Office, Afe Babalola University, Ado-Ekiti, Nigeria \\ Email address: \\ folayanifeoluwa@gmail.com \\ To cite this article: \\ Adebiyi Ifeoluwa Mary. Impact of Effective Internal Control in the Management of Mother and Child Hospital Akure, Ondo State. Journal \\ of Finance and Accounting. Vol. 5, No. 1, 2017, pp. 61-73. doi: 10.11648/j.jfa.20170501.16
}

Received: November 27, 2016; Accepted: December 7, 2016; Published: March 6, 2017

\begin{abstract}
The research reviewed and evaluated the activities of Mother and Child Hospital, Akure in Ondo State using a sample size of 50 respondents, randomly selected via questionnaire for data collection and the data was analyzed with the use of chi-square test statistics. The result showed that internal control had significant effect on the management of government parastatals. It was concluded that adequate internal control should be maintained as well as strict adherence to management policies ensured so as to achieve the set objectives for the parastatals.
\end{abstract}

Keywords: Internal Control, Internal Audit, Internal Check, Management, Parastatals

\section{Introduction}

The most important information needed by management for planning, decision-making, controlling and evaluation of performance comes from accounting records and this information must be reliable, complete, and timely to be of maximum use [30]. Internal control, to a great extent contributes to the attainment of these objectives and had there not been the development and recognition of internal control as a useful management tool, the effective auditing of accounting records of modern day corporate bodies would have become simply unattainable.

Internal Control is "the whole system of control, financial or otherwise, established by the management in order to carry on the business of the enterprise, in an orderly and efficient manner, ensure adherence to management policies, safeguard the assets and secure as far as possible the completeness and accuracy of the record [20]". The individual components of an internal control system are known as 'controls' or internal controls'. Internal controls are to be an integral part of an organization's financial and business policies and procedures It consists of all the measures taken by the organization for the purpose of; protecting its resources against fraud, waste and inefficiency, ensuring accuracy and reliability in accounting and operating data, securing compliance with the policies of the organization and evaluating the level of performance in all organizational units [7], [17]. Internal controls are simply good business practices.

The impact of effective internal control in the management, growth and survival of institutions, companies and government parastatals cannot be overemphasized as it is useful in the safeguard of assets and to ensure completeness and accuracy of records. Government parastatals like every enterprise require a sound internal control in the effective management of their operations and as mentioned by [2]. It is seen by most organizations as important ingredients for the survival of business enterprises and government agencies.

A parastatal is defined as a company or agency owned or controlled wholly or partly by the government. Parastatals perform specific roles in a country and their activities are found in such areas as transport, communication, financial and management, production and marketing. They are established to provide services that are generally in public interest that private sector may not provide due to high capital investment needed at initial stages [12].

A good internal control system would serve as a control in government parastatals. When a good internal control does not exist, the top management of these parastatals will not be aware of the trends in various areas of operation and will not consequently be able to take necessary corrective action. Although, internal control cannot completely get rid of all errors and irregularities, but they can call management attention to potential problems [21]. Management should 
always pay particular attention to the internal control system in their enterprise.

It is against this background that this study seeks to unveil and look at the place, importance and inevitable nature of internal control system in government parastatals; its impact on its management, growth and survival.

\section{Literature Review}

When institutions suddenly collapse, the often-resounding question is, "what went wrong?" A breakdown in the internal control system is often stated as the usual cause. Internal control is a process that guides an organization towards achieving its objectives. These objectives include operational efficiency and effectiveness, reliability of financial reporting and compliance with relevant laws and regulations [8]. Absence of these variables often result in organizational failure. The findings of the Treadway Commission Report of 1987 in the United States (USA) confirmed absence of or weak internal controls as the primary cause of many cases of fraudulent company financial reporting.

\subsection{Internal Control Concept and Definition}

Internal controls are all of the policies and procedures management uses to safeguard assets, ensuring the reliability and integrity of financial information, ensure compliance, promote efficient and effective operations and accomplishment of goods and services achieve the following goals [25], [31].

[22] defined Internal Controls as methods put in place by a company to ensure the integrity of financial and accounting information meet operational and profitability targets, and transmit management policies throughout the organization. [12] defined it as all the policies and procedures adopted by the management of an entity to assist in achieving management objective of ensuring as far as practicable, the orderly and efficient conduct of it business, including adherence to management policies, the safeguarding of assets, the prevention and detection of fraud and error, the accuracy and completeness of accounting records, and the timely preparation of reliable financial information. It is a system consisting of specific policies and procedures designed to provide management with reasonable assurance that the goals and objectives it believes important to the entity will be met.

[3] stated that "It is not only internal check and internal audit, but the whole system of controls, financial and otherwise, established by the management in order to carry on the business of the enterprise in an orderly and efficient manner, ensure adherence to management policies, safeguard the assets and secure as far as possible the completeness and accuracy of the records". This definition embraces many control features. It includes all types of controls which are necessary for the operation of an activity in an organization. Internal check and internal audit are stated to be the essential elements of internal control.

The American Institute of Certified Public Accountants (AICPA) according to [27] has a very close resemblance with the definition given above, it reads as follows:

"Internal control comprises the plan of organization and all the coordinate measures adopted within a business to safeguard its assets, check the accuracy and reliability of its accounting data, promote operational efficiency, and encourage adherence to prescribed managerial policies. The definition of internal control has gone through several revisions by various authoritative institutions. It also defines internal accounting control as follows: [Internal] Accounting control comprises the plan of organization and the procedures and records that are concerned with the safeguarding of assets and the reliability of financial records".

This above definition identifies the goals of internal accounting control and the general types of practices included in an accounting system for achieving these goals. As indicated by this definition, the main goals of internal accounting controls include: (1) safeguarding of assets against loss arising from unintentional or intentional errors in processing transactions and handling the related assets, and (2) maintaining the reliability of financial records for external reporting purposes.

An internal control system might incorporate elements beyond the accounting and financial activities to which many accountants think internal control are limited. Such elements include: 'budgetary control, standard costs, periodic operating reports, statistical analyses and the dissemination thereof, a training program designed to aid personnel in meeting their responsibilities, and an internal audit staff to provide additional assurance to management as to the adequacy of its outlined procedures and the extent to which they are being effectively carried out. It properly comprehends activities in other fields as, for example, time and motion studies which are of an engineering nature and use of quality controls through a system of inspection which fundamentally is a production'.

Internal control is sometimes divided into administrative and accounting controls [4].

\subsection{Definition of Parastatal}

[6] defines parastatals as special organizations established with the purpose of executing some specified services to the public. They are set up by the State or Federal Government to provide services to the people. They are sometimes referred to as statutory corporations, and some of them are set up like companies. Examples include utility corporations like Water Corporation, Government hospitals, Power Holding Company of Nigeria (PHCN), Waste Management Boards, Radiovision/Television Corporation e.t.c.

Parastatals are taken to include government business enterprises and state-owned corporations and other organisations including boards, agencies, commissions and institutions which are established as semi-autonomous entities with their own governing bodies. They are special organizations established with the purpose of executing some special services to the public. They are set up by the State or Federal Government to provide services to the people [6]. 
Usually a parastatal is served by an enabling act which states the following: The name of the parastatal, the objectives of the parastatal, the place where the head office and branch offices of the parastatals will be sited, the organogram of the organization consisting of the directors, managers, other officers stating their respective functions and basis of appointing them, the sources of fund for the parastatals and the type of accounts they are expected to keep. The sources of revenue to parastatals are recurrent revenue subvention, capital revenue subvention, loans.

Recurrent revenue subvention; are subventions that are obtainable on monthly basis; they are applied for the day-today running of the parastatals. Capital revenue subvention; are subventions obtainable on quarterly, yearly or occasional basis. They are applied on capital expenditures e.g. replacement of plant and machinery, construction of buildings, factories, procurement of implements in large quantities. Loans; parastatals also obtain loans from the government or source for loan abroad through the government [6].

Parastatals are not set up to make profit but to provide welfare services to the citizens at a lower rate if not absolutely free and as such government provide enough fund (known as subvention) to them to run the organization.

For these parastatals to run efficiently and effectively and for proper accountability, a sound internal control system is to be put in place. It will help to ensure that activities are continuously monitored and adequately controlled. Hence, this study seeks to examine how established internal control impacts on the management of government parastatals with particular reference to Mother and Child Hospital Akure.

\subsection{Historical Background of Mother and Child Hospital, Akure, Ondo State}

Medical experts have on many occasions, described Nigerian women as the most fertile and productive in the world. The reason is not far to seek. All cultures in Nigeria place premium on the ability to produce as many children as possible as indication of God's blessing on it. It is also considered a good index to measure the strength and wealth of the man.

As good as it appears, little attention is paid to the care of the child and the mother, who in most cases bear the brunt of delivering and raising the children. Our women have as many as between five and eight or more children in our unfriendly environment where hospitals and health centres are inadequate, essential drugs and medical personnel in short supply. But government over the years have only been paying lip service to the health status of its citizens, except for image laundering publicity when the need arises.

In Ondo State, the World Bank team carried out an independent assessment of the health care of the state and came out with a bombshell that rated the state as the worst in the South-Western part of the country. Using health indices, the state had an unenviable record of high rate of infant and maternal mortality.

Also, Mrs. Anne Okigho-Fisher, the leader of the World
Bank Health System Development Project (HSDP II), during a working visit to the state, stunned the state governor, Dr. Olusegun Mimiko that, the billions of naira supposedly spent on the health sector in the past years had not yielded the expected result, given the state's high record of infant and maternal mortality, a situation which she regretted was unacceptable and which must be urgently tackled.

Before the Labour Party took over the reins of power in the state in 2009, hospitals particularly the ante-natal and children were daily bombarded with pregnant women and children, who would wait endlessly for hours for doctors who attended to hundreds of patients before close of work. There were also instances when patients have to visit hospitals for 2 or 3 days before having the opportunity to see a doctor for diagnosis.

Statistics showed that about 150 pregnant women on the average visited the State Specialist Hospital, Akure on every antenatal day, while same hospital recorded about 200 patients on the average at the children's unit on daily basis. This is bearing in mind that health care service in the nation is still at low ebb, Ondo State inclusive, shortage of personnel and equipment, high cost of treatment, influx of fake drugs with attendant increase in mortality.

The foregoing was the situation of things when Dr. Olusegun Mimiko came to power on February 24, 2009. No sooner had the government resumed office than he visited the State Specialist Hospital in Akure, where he was confounded with a gory scenario of overcrowded antenatal and children's units, during which mothers appealed to the governor to urgently address the ugly situation.

The governor, who was a two-term Commissioner for Health in the state and pioneer medical doctor to rule the state since its creation, needed no conviction to push him into action to turn things around in the health sector, starting with commitment to reduce infant and maternal mortality. As a demonstration of this commitment, the government came up with the idea of having a separate hospital dedicated to the care of the child and mother as one sure way of decongesting the conventional hospitals in the state and providing a platform for quality and prompt healthcare delivery to women and children.

In translating this idea into reality, the administration on May 13, 2009 had a ground breaking ceremony of the first ever Mother and Child Hospital at Oke-Aro in Akure.

Consequently, the administration started to develop new medical infrastructure in a number of locations all over the state, beginning from Akure which is the state capital, to bring health care to the doorsteps of the people and also significantly reduce the long queues and frustration on the people's part".

It is heart-warming to note that the first Mother and Child Hospital project was completed and has ever being in use. The hospital is made up of several waiting rooms, blood bank, pharmacy, and doctors' quarters among others.

The organogram of mother and child hospital at Oke-Aro, Akure in Ondo state is as shown in fig. 1 


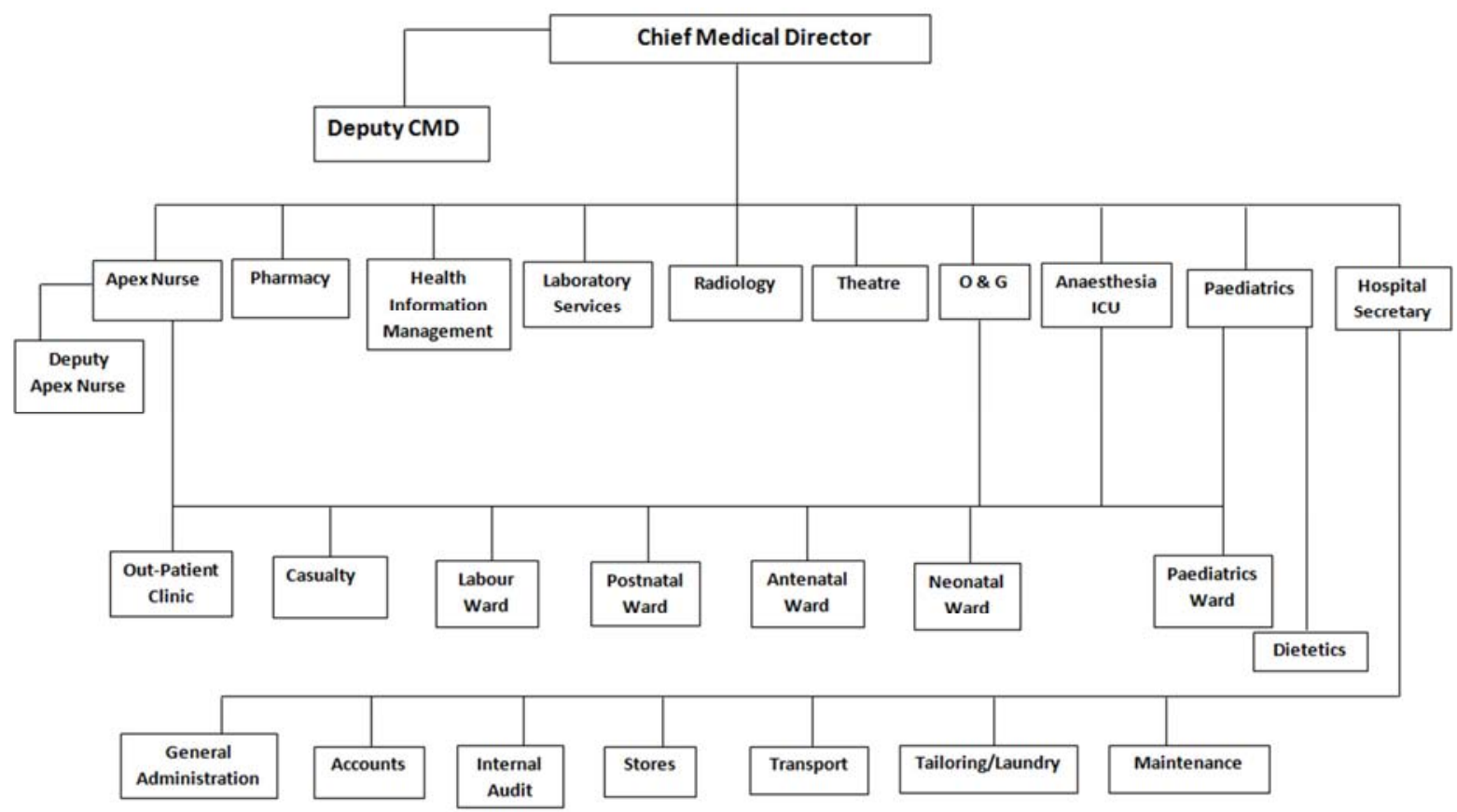

Fig. 1. Organisational Structure of Mother and Child Hospital Oke-Aro, Akure, Ondo State.

\section{Statement of the Problem}

Due to inefficient internal control system in government parastatals and some other organizations; it is difficult to present a true and fair view of the enterprise's financial statement, which is very important because it gives assurance of the continuous existence of the organization in the nearest future and the attainment of their stated objectives.

However, the causes of these problems are due to the following:

- Improper record keeping of payments and receipts which could lead to inability to ascertain the parastatal's actual assets; goods in stock, which could breed pilfering.

- Improper clear definition or delegation of duties, responsibilities and powers of each department.

- Inefficiency in the internal control system in government parastatals.

- An inappropriate system of reporting to management.

The non-institution of internal control system could lead to inability of the parastatal to make proper decisions and plan ahead effectively. When an organization fails to plan, definitely it will forestall the growth of the parastatal; make it to start dwindling and struggling for survival, which will then bring the parastatal to an end.

Thus, this study examined the impact of effective internal control in the management of government parastatals with particular interest in the Mother and Child Hospital, Akure Ondo State.

\section{Objective of the Study}

The main objective of this research work is to evaluate the impact of effective internal control in the management of government parastatals with special reference to Mother and Child Hospital Akure, Ondo State. Other objectives of this study include:

- To determine and examine the effectiveness of the Internal Control System in government parastatals in safeguarding assets, controlling fraudulent activities and maintaining accuracy and completeness of records.

- To ascertain the extent to which fraud and errors can be detected early and corrected.

- To examine the extent to which the Internal Control System has helped the management in achieving set goals and objectives.

- To identify flaws (if any) in the internal control system and proffer solutions to them.

\section{Research Questions}

1) Does the installation of an internal control system have any effect on the performance of management of government parastatals?

2) Does internal control affect the growth and survival of government parastatals?

3) How can internal control in government parastatals be improved?

4) Are there limitations in the application of internal control in government parastatals?

\section{Research Hypothesis}

\section{Hypothesis I}

$\mathrm{H}_{0}$ Installation of internal control system has no significant effect on the performance management of government 
parastatals.

$\mathrm{H}_{1}$ Installation of internal control system has a significant effect on the performance of management of government parastatals.

\section{Hypothesis II}

$\mathrm{H}_{0}$ Installation of internal control system has no significant effect on the growth and survival of government parastatals.

$\mathrm{H}_{1}$ Installation of internal control system has a significant effect on the growth and survival of government parastatals.

\section{Components of Internal Control}

Internal control system operates at different levels of effectiveness. Determining whether a particular internal control system is effective is a judgment resulting from an assessment of whether the five components- control environments, risk assessment, control activities, information and communication and monitoring are present and functioning [15].

The internal control components are interrelated and they include:

The Control (Operating) environment, Risk assessment, Control activities, Information and Communication, Monitoring [8], [9], [16].

\subsection{Control Environment}

The control environment is the control consciousness of an organization; it is the atmosphere in which people conduct their activities and carry out their control responsibilities. An effective control environment is an environment where competent people understand their responsibilities, the limits to their authority, and are knowledgeable, mindful, and committed to doing what is right and doing it the right way. They are committed to following an organization's policies and procedures and its ethical and behavioral standards. The control environment encompasses technical competence and ethical commitment; it is an intangible factor that is essential to effective internal control.

\section{Control environment tips}

Effective human resource policies and procedures enhance an organization's control environment. These policies and procedures should address hiring, orientation, training, evaluations, counseling, promotions, compensation, and disciplinary actions. In the event that an employee does not comply with an organization's policies and procedures or behavioral standards, an organization must take appropriate disciplinary action to maintain an effective control environment. The control environment is greatly influenced by the extent to which individuals recognize that they will be held accountable [13].

\subsection{Risk Assessment}

Risk assessment refers to the identification, analysis and management of uncertainty facing the organization. Risk assessment focuses on the uncertainties in meeting the institution's financial compliance and operational objectives. [9] stated that they are events that threaten the achievement of an organization's objectives. Management need to take actions to prevent the internal and external risks that could affect the establishment of set objectives at every organizational level. There is the need to determine whether to accept, reduce the risk up to acceptable levels or avoid it.

\subsection{Control Activities}

Control activities are the policies and procedures that help ensure that management directives are carried out. They help ensure that necessary actions are taken to address risks to achievement of the entity's objectives. Control activities occur throughout the organization, at all levels and in all functions. They include a range of activities such as approvals, authorizations, verifications, reconciliations, reviews of operating performance, security of assets and segregation of duties [9]. The components of control activities include personnel authorization procedures and segregation of duties [27].

\subsection{Information and Communication}

It focuses "on the nature and quality of information needed for effective control, the system used to develop such information and reports necessary to communicate it effectively" (internal control issues). Pertinent information must be identified, captured and communicated in a form and time frame that enable people to carry out their responsibilities.

\subsection{Monitoring}

Monitoring is the assessment of internal control performance over time; it is accomplished by ongoing monitoring activities and by separate evaluations of internal control such as self-assessments, peer reviews, and internal audits. The purpose of monitoring is to determine whether internal control is adequately designed, properly executed, and effective. Internal control is adequately designed and properly executed if all five internal control components (Control Environment, Risk Assessment, Control Activities, Information and Communication, and Monitoring) are present and functioning as designed.

\subsection{Types of Internal Control System}

The types of internal control that can be put in place in any organization include: physical control, authorization and approval, personnel control, arithmetic and accounting control managements control, organizational control, segregation of duties [11].

Internal control is primarily effected by an entity's internal stakeholders including management, internal auditors and other staff. However, the actions of external stakeholders also impact the internal control system.

\subsection{Conditions for a Functional Internal Control System}

The conditions to guarantee a functional Internal Control System according to [11] include: 
- Management should not override laid-down control.

- The object of Internal Control must be communicated to all staff.

- Internal Control System must be documented for future reference.

- Personnel in charge of handling the hospital's activities should have adequate training, experience, proficiency and be well motivated.

- There should be a clearly defined organisational structure showing the division of duties.

- There should be a periodic review of laid down control by management.

- The Internal Control System should not be too complex i.e. it must be simple.

It must be emphasized that objective of Internal Control is to limit the occurrence of errors and fraud to the barest minimum. No matter how effective a client's Internal Control is, errors and fraud can occur by collusion, abuse of authority, human errors and management exceptions.

\subsection{Benefits of Control}

A sound internal control framework according to will provide effective operation, and a clear view of risk. Effective internal control system in Mother and Child Hospital Akure, will assure the following:

(1) That the hospital's operations are conducted in an orderly and efficient manner.

(2) That the hospital's assets are safeguarded.

(3) That there is completeness, accuracy and validity of the hospital's record.

(4) That records and information provided will be useful for planning, controlling and decision making.

(5) That there is readily available data for performance evaluation.

It has been revealed that no amount of internal and external pressures will make an institution or organization administratively efficient unless it is properly managed and controlled by the management [1]. Therefore, the management of the hospital should introduce adequate and effective internal control system which would minimize risk of irregularities, ensure adherence to management policies, ensure completeness, accuracy and validity of the records and finally ensure that the resources are used in an effective and efficient manner.

\subsection{Weaknesses and Specific Failures Associated with Internal Control System}

No Internal Control System, however elaborate can itself guarantee efficient administration and the completeness and accuracy of the records; nor can it be a proof against fraudulent collusion. Internal control that depends on segregation of duties can be avoided by collusion. Authorization control can be abused by the person in whom the authority is vested. Management is frequently in a position to override controls that it has itself established.

There are many factors, which may obviate the effectiveness of internal controls. Those factors include Incompetence, Lack of integrity, Fatigue, Human error. According to [19], human error, collusion of employee, management abuse of control, abuse of authorization control pressure are inherent limitations connected with internal control.

In most business organizations, internal control can be applied in the areas of Fixed Assets, Petty Cash, Wages and Salaries.

\section{A Internal control over fixed asset}

1) Fixed asset should be kept physically secured.

2) There should be a register of fixed asset recording the historical details of each class of asset.

3) Acquisition and Disposal of fixed asset must be validly authorized.

4) The use of fixed asset must be authorized at all times by a responsible official.

5) Segregation of duty should be observed in processing fixed asset transactions.

6) There should be periodic and physical inspection of fixed asset.

7) There should be controls to ensure that fixed asset is being written off over estimated useful life of the asset as provided by the standard.

\section{$B \quad$ Internal control over wages and salaries}

The internal control system is vital regarding employee remuneration. The checks which an auditor should carry out include:

1) There should be satisfactory procedures for appointments, dismissals, promotions, fixing starting rate of pay and changes in the rates of pay;

2) Checking of how the records of all notifications of changes in personnel and salaries are recorded.

3) The preparation of payroll should be distributed among a number of employees and duties of staff preparing the payroll should be rotated.

4) Where payments are in cash, the auditor must ensure that there is strict control over the payment of wages and salaries in cash.

5) There should be physical attendance of individual employees in receiving salaries and wages whether in cash or by cheques.

6) Payroll procedures should ensure calculation of gross pay, total deduction and net pay. The payroll should be approved by authorized officials before payments are made.

7) Specific arrangement should be made for dealing with unclaimed wages.

\subsection{Internal Audit and Internal Check}

\subsubsection{Internal Audit}

Internal audit constitutes an important element of the Internal Control System. [14] defines it as an independent appraisal function established by the management of an organisation for the review of the internal control system as a service to the organisation. It examines objectively, evaluates and reports on the adequacy of internal control as a contribution to the proper, economic and effective use of resources. 
The above definition of Internal Audit by [14] indicates that Internal Audit will subject internal check to independent appraisal and valuation.

[28] defined it as an independent, objective, assurance and consulting activity designed to add value and improve an organisation's operations. It helps to accomplish an organisation's objectives by bringing a systematic disciplined approach to evaluate and improve the risk management, control and governance process.

It is right to say that Mother and Child Hospital Akure creates an Internal Audit to supplement, appraise and evaluate the check procedures and all other internal controls incorporated into the system.

The primary purpose of internal audit accesses the effectiveness and efficiency of the accounting and internal control system and makes appropriate recommendations to the management as to how weaknesses could be corrected. The internal audit department/unit and the system laid down are adequate to minimize the risk of irregularities.

\subsubsection{Internal Check}

Internal check is the aspect of internal control which is exclusively concerned with prevention and early detection of fraud [19]. It involves the arrangement of book keeping and other clerical duties in such a way as to ensure that:

- No single task is executed from the beginning to its conclusion by one person.

- That the work of each person engaging on a task is subject to independent check in the course of another's duties.

Internal check is a valuable part of internal control it is built-in check in accounting process itself. Internal check is provided by segregating duties in such a -way that no one person can initiate, authorize, conduct and record a transaction from start to finish without his work coming under the surveillance of at least one other person.

It is an arrangement of staff duties whereby no one person is allowed to carry through and to record every aspect of a transaction so that without collusion between two or more persons, fraud is prevented and at the same time possibilities of errors are reduced to a minimum. Thus, internal check means the arrangement of duties of staff in such a manner that the work of one person is automatically checked by another during the course of carrying out, recording and processing a transaction.

\section{Research Methodology}

The research methodology includes method used in the collection of data, characteristics of the study population, sampling design and procedure, data collection instruments, validity design and procedure, validity test and reliability of data collection instruments and procedure for processing and analysis of the collected data and limitation of the methodology [5], [18].

The sources of data collection were mainly from the primary and secondary sources for the purpose of reaching desired goal of providing useful suggestion on the Impact of Effective Internal Control in the Management of Government
Parastatals. A case study of Mother and Child Hospital, Akure, Ondo State.

\subsection{Sources of Data}

In conducting this research, two sources of data were used as previously mentioned. They are:

(1) Primary source

(2) Secondary source.

\subsubsection{Primary Method of Data Collection}

This includes the Questionnaire, Interview and Observation. For the purpose of this study, personal interviews were conducted and questionnaires distributed by the researcher to the staff of Mother and Child Hospital OkeAro, Akure, Ondo State. The questionnaire was also drawn in order to detect whether the necessary internal control systems are in existence in the hospital and whether they are strictly observed in the day to day operation of the hospital. These methods enabled the researcher to obtain reliable and valid information from the respondents.

\subsubsection{Secondary Data as a Method of Data Collection}

These are information that have been used for some purpose other than that for which they were originally collected. For the purpose of this research work, the researcher made use of magazines, internet, journals articles, papers presented at workshops, seminars and conferences, textbooks, related project and lecture notes related to the topic. The advantage of the secondary data is that less effort is required for its collection.

\subsection{Population and Sample Description}

The population of this study cuts across all government parastatals. Since all the government parastatals cannot be covered, the sample size of 50 was randomly selected from the staff of Mother and Child Hospital Oke-Aro, Akure, Ondo State (Government Hospital) to represent the population, which is of a good mix of male and female staff ranking from the top to lower management.

\subsection{Description of Questionnaire}

The questionnaire is divided into two sections: Section a containing information on the personal data of the respondents. Section B containing Closed-Ended Questions using the Likert-Summated Rating Scale.

\subsection{Method of Data Analysis and Description of Tools of Analysis}

The hypotheses were tested using chi-square method.

Chi-square $(x)^{2}$ is the sum of ratio of differences between observed and expected frequencies. It is used to measure the degree of deviation that exist between a calculated value and the critical value of variables in terms of a given criteria. Chisquare $(\mathrm{x})^{2}$ is calculated using the formula.

The formula is given below: 


$$
X^{2}=\frac{\Sigma(O-E)^{2}}{E}
$$

Where $\mathrm{O}=$ the observed frequency and

$\sum=$ the expected frequency.

The chi-square $(\mathrm{x})^{2}$ distribution depends on a quality referred to as the " degree of freedom" which is derived by applying $\mathrm{r}-1$ for a single row of r-cells and ( $\mathrm{r}-1)(\mathrm{c}-1)$ for multiple rows and columns; where $r=$ numbers of rows and c- numbers of columns.

The result of the above calculation was computed with $\mathrm{X}$ table value for the purpose of making decision either accepting or rejecting the hypothesis. The $\mathrm{X}$ table value is obtained as follows.

$\mathrm{X}^{2}$ tab where

$\mathrm{V}$ (the degree of freedom) $(\mathrm{r}-1)(\mathrm{c}-1)$ for multiple rows (r-1) for single row of cell

The condition for accepting or rejecting hypothesis is explained below:

i. Reject the null hypothesis (and accept alternative hypothesis) if calculated $\left(\mathrm{x}^{2} \mathrm{c}\right)$ value is greater than tabulated value $\left(\mathrm{x}^{2} \mathrm{t}\right)$.

ii. Accept the null hypothesis and reject alternative hypothesis if calculated value $\left(x^{2} c\right)$ is less than tabulated value $\left(x^{2} t\right)$.

\subsubsection{Data Presentation and Analysis}

The data was collected through the administration of questionnaires which was classified, tabulated and analyzed for making references. The data and information was analyzed in order to arrive at a logical conclusion based on the information provided by the staff of Mother and Child Hospital Akure, Ondo State.

\subsubsection{Data Collection and Analysis}

In the course of this research work, fifty (50) questionnaires were administered but only forty-two (42) questionnaires were correctly completed and returned. This presumed that forty-two (42) employees were used for the sample. The tabular presentation of the distribution of questionnaire and responses obtained are shown in table 1

Table 1. Analysis of questionnaires.

\begin{tabular}{lll}
\hline Classification & $\begin{array}{l}\text { Number of } \\
\text { questionnaires }\end{array}$ & $\begin{array}{l}\text { Percentage } \\
(\%)\end{array}$ \\
\hline Questionnaires returned & 42 & 84 \\
Questionnaires unreturned & 8 & 16 \\
TOTAL & 50 & 100 \\
\hline
\end{tabular}

Source: ield Survey 2012

Forty two (42) questionnaires representing $84 \%$ of the total questionnaires were correctly filled and returned while only 8 which represents $16 \%$ were not returned at all.

\subsection{Demographic Characteristics of Respondents}

Table 2 showed the demographic distribution in terms of gender, age, marital stations, educational qualification and length of service of the respondents in the study.
That out of the 42 respondents 27 respondents (65\%) who responded to the questionnaire were female while 15 respondents $(35 \%)$ were male. This indicates that majority of the employees of the hospital are female.

It showed that $13(31 \%)$ of the respondents fell within the ages of 31-40 years, 12 (29\%) of the respondents fell within the ages of 20-30 years, followed by 41-50 years with 8 (19\%) of the respondents and 51 years and above with just 9 respondents representing $21 \%$. This indicates that majority of the respondents were between the ages of 31-40 years.

The table indicates that $32(76.2 \%)$ of the respondents were married while $10(23.8 \%)$ of the respondents were single. This implies that majority of those who are involved in the hospital operations were married.

Also, $18(42.86 \%)$ of the respondents had educational qualification in different fields, $12(28.57 \%)$ of the respondents had B.SC/HND as their highest educational qualification, $8(19.05 \%)$ of the respondents had OND/NCE as their highest educational qualification and the remaining 4 representing 9.52\% have M.SC / M.BA. Therefore, most of our respondents are Professionals education.

The table showed that $28(66.7 \%)$ of the respondents had spent 1-10 years on the job, 9 (11.9\%) of the respondents had spent 21 years and above on the job while the remaining 5 representing $21.4 \%$ of the respondents had spent $11-20$ years on the job. This indicates that most of the respondents had spent between 1-10 years on the job.

Table 2. Demographic Characteristics of Respondents.

\begin{tabular}{|c|c|c|}
\hline Sex distribution & No of respondents & Percentage (\%) \\
\hline Male & 15 & 35.7 \\
\hline Female & 27 & 64.3 \\
\hline Total & 42 & 100 \\
\hline Age range & No of the respondents & Percentage (\%) \\
\hline $20-30$ years & 13 & 31 \\
\hline $31-40$ years & 12 & 29 \\
\hline $41-50$ years & 8 & 19 \\
\hline 51 years and above & 9 & 21 \\
\hline Total & 42 & 100 \\
\hline Marital status & No of respondents & Percentage $(\%)$ \\
\hline Married & 32 & 76.2 \\
\hline Single & 10 & 23.8 \\
\hline Total & 42 & 100 \\
\hline Qualification & No of respondents & Percentage (\%) \\
\hline $\mathrm{OND} / \mathrm{NCE}$ & 8 & 19.05 \\
\hline B.SC/HND & 12 & 28.57 \\
\hline M.BA/M.SC & 4 & 9.52 \\
\hline $\begin{array}{l}\text { Professional } \\
\text { Qualification }\end{array}$ & 18 & 42.86 \\
\hline Total & 42 & 100 \\
\hline $\begin{array}{l}\text { No of years (Length of } \\
\text { Service) }\end{array}$ & No of respondents & Percentage (\%) \\
\hline $1-10$ years & 28 & 66.7 \\
\hline $11-20$ years & 5 & 11.9 \\
\hline 21 years and above & 9 & 21.4 \\
\hline TOTAL & 42 & 100 \\
\hline
\end{tabular}

Source: Field Survey 2012

\subsection{Internal Control in the Hospital}

Table 3 revealed that respondents' opinion on the 
effectiveness of internal control measures, need for internal control; impact on the performance, growth and survival, management, limitations in the application of internal control, effect on fraud, efficiency. It also showed their opinion on how internal control has helped in safeguarding assets, controlling fraud, maintaining accuracy and completeness of records in the hospital.

The table indicated that $26(62 \%)$ of the respondents agreed that there were internal control measures in the hospital, $15(36 \%)$ strongly agreed while 1 (2\%) were undecided. This implied that majority of the respondents were aware of the internal control measures instituted in the hospital.

The table further showed that $21(50 \%)$ of the respondents strongly agreed and $15(36 \%)$ agreed that internal control is necessary in an organization for effective performance and control while $6(14 \%)$ of the respondents were undecided.

According to the table, internal control had impacted positively on the performance level of their hospital since majority of the respondents i.e. $24(57 \%)$ agreed and 15 (36\%) strongly agreed to this, while $3(7 \%)$ were unable to decide.

It showed that $24(57 \%)$ and $12(29 \%)$ of the respondents agreed and strongly agreed respectively that the installation of internal control system had an effect on the growth and survival of their hospital, $3(7 \%)$ of the respondents were unable to decide, $2(5 \%)$ disagreed while 1 representing $2 \%$ of the respondents strongly agreed.

The table indicated that $18(43 \%)$ of the respondents strongly agreed that the installation of internal control system had an effect on the performance of management of their hospital, 12 (29\%) agreed, 8 (19\%) were unable to decide while $3(7 \%)$ of the respondents disagreed while $1(2 \%)$ strongly disagreed.

The table further indicated that, $21(50 \%)$ of the respondents agreed that there were limitations in the application of internal control in the hospital, $9(21.42 \%)$ of the respondents disagreed, 6 (14.29\%) strongly agreed while the remaining $6(14.29)$ were unable to decide.

Also, $18(43 \%)$ strongly agreed that ineffective internal control breed fraud, 12 (29\%) agreed, 6 (14\%) were undecided, while $4(10 \%)$ and $2(4 \%)$ of the respondents disagreed and strongly disagree respectively

The table showed that $22(52 \%)$ of the respondents strongly agreed that internal audit is efficient in the application of internal control in mother and child, 18 (43\%) agreed, while $2(5 \%)$ chose undecided.

It showed that $24(57.14 \%)$ of the respondents agreed that installation of internal control system had helped in safeguarding assets, controlling fraudulent activities and maintaining accuracy and completeness of records in the hospital, $9(21.43 \%)$ of the respondents strongly agreed to this, $6(14.29 \%)$ were undecided while the remaining 3 $(7.14 \%)$ of the disagreed.

Table 3. Internal Control, its impact and effectiveness in the Hospital.

\begin{tabular}{|c|c|c|}
\hline Description & No of respondents & Percentage $(\%)$ \\
\hline \multicolumn{3}{|c|}{ There are effective internal control measures in your hospital. } \\
\hline Strongly & 15 & 36 \\
\hline Agree & 26 & 62 \\
\hline Undecided & 1 & 2 \\
\hline Disagree & - & - \\
\hline Strongly Disagree & - & - \\
\hline TOTAL & 42 & 100 \\
\hline Strongly Agree & 21 & 50 \\
\hline Agree & 15 & 36 \\
\hline Undecided & 6 & 14 \\
\hline Disagree & - & - \\
\hline Strongly Disagree & - & - \\
\hline TOTAL & 42 & 100 \\
\hline \multicolumn{3}{|c|}{ There are limitations in the application of internal control in your hospital. } \\
\hline Strongly Agree & 15 & 36 \\
\hline Undecided & 3 & 7 \\
\hline Disagree & - & - \\
\hline Strongly Disagree & - & - \\
\hline TOTAL & 42 & 100 \\
\hline \multicolumn{3}{|c|}{ The installation of internal control system has an effect on the growth and survival of your hospital. } \\
\hline Strongly Agree & 12 & 29 \\
\hline Agree & 24 & 57 \\
\hline Undecided & 3 & 7 \\
\hline Disagree & 2 & 5 \\
\hline Strongly Disagree & 1 & 2 \\
\hline TOTAL & 40 & 100 \\
\hline \multicolumn{3}{|c|}{ The installation of internal control system has an effect on the performance of management of your hospital. } \\
\hline Strongly Agree & 18 & 43 \\
\hline Agree & 12 & 29 \\
\hline Undecided & 8 & 19 \\
\hline
\end{tabular}




\begin{tabular}{|c|c|c|}
\hline Description & No of respondents & Percentage (\%) \\
\hline \multicolumn{3}{|c|}{ There are effective internal control measures in your hospital. } \\
\hline Strongly Disagree & 1 & 2 \\
\hline TOTAL & 42 & 100 \\
\hline \multicolumn{3}{|c|}{ There are limitations in the application of internal control in your hospital. } \\
\hline Strongly Agree & 6 & 14.29 \\
\hline Agree & 21 & 50 \\
\hline Undecided & 6 & 14.29 \\
\hline Disagree & 9 & 21.42 \\
\hline Strongly Disagree & - & - \\
\hline TOTAL & 42 & 100 \\
\hline \multicolumn{3}{|c|}{ Ineffective internal control breeds fraud. } \\
\hline Strongly Agree & 18 & 43 \\
\hline Agree & 12 & 29 \\
\hline Disagree & 6 & 14 \\
\hline Undecided & 4 & 10 \\
\hline Strongly Disagree & 2 & 4 \\
\hline TOTAL & 42 & 100 \\
\hline \multicolumn{3}{|c|}{ Internal audit is efficient in the application of internal control system in mother and child. } \\
\hline Strongly Agree & 22 & 52 \\
\hline Agree & 18 & 43 \\
\hline Undecided & 2 & 5 \\
\hline Disagree & - & - \\
\hline Strongly Disagree & - & - \\
\hline TOTAL & 42 & 100 \\
\hline \multicolumn{3}{|c|}{$\begin{array}{l}\text { The installation of internal control system has helped in safeguarding assets, controlling fraudulent activities and maintaining accuracy and } \\
\text { completeness of records in the hospital. }\end{array}$} \\
\hline Strongly Agree & 9 & 21.43 \\
\hline Agree & 24 & 57.14 \\
\hline Undecided & 6 & 14.29 \\
\hline Disagree & 3 & 7.14 \\
\hline Strongly Disagree & - & - \\
\hline TOTAL & 42 & 100 \\
\hline
\end{tabular}

Source: Field Survey 2012

In Table 4 respondents' opinion indicated that there was segregation, rotation of duties, documentation operational efficiency, effective management, determination of success and minimization of fraud and irregularity by internal control system.

Table 4 showed that $22(52.3 \%)$ strongly agreed that internal check as an administrative control has minimized the risk of fraud and irregularities in the hospital, 15 (36.7\%) agreed, 3 (7.14) were unable to decide, 1 (2.38) disagreed and strongly disagreed.

Table 4 showed that there was segregation and rotation of duties among workers in hospital as $27(64 \%)$ and $15(36 \%)$ of the respondents strongly agreed and agreed respectively.

The Table showed that $15(36 \%)$ agreed that there was proper documentation of transactions in their hospital, 12 $(29 \%)$ strongly agreed, $9(21 \%)$ were undecided, 3 (7\%) disagreed while the remaining $3(7 \%)$ strongly disagreed.

The table showed that $21(50 \%)$ of the respondents agreed that the internal control system installed has contributed to the operational efficiency and effective management of this hospital, $12(29 \%)$ agreed to this, $6(14 \%)$ were unable to decide while 3 (7\%) of the respondents disagreed to this.

As shown in table, it can be deduced that $15(36 \%)$ of the respondents agreed that the individual implementing internal control determines its success or otherwise, $11(26 \%)$ strongly agreed, 7 (17\%) disagreed, $6(14 \%)$ were undecided while $3(7 \%)$ of the respondents strongly disagreed.
Table 4. Segregation, rotation, documentation, implementation of internal control and internal check.

\begin{tabular}{lcc}
\hline Description & No of respondents & Percentage (\%) \\
\hline \multicolumn{2}{l}{ There is segregation and rotation of duties among workers in your } \\
hospital. & & \\
Strongly Agree & 27 & 64 \\
Agree & 15 & 36 \\
Undecided & - & - \\
Disagree & - & - \\
Strongly Disagree & - & - \\
TOTAL & 42 & 100 \\
There is proper documentation of transactions in your hospital. \\
Strongly Agree & 12 & 29 \\
Agree & 15 & 36 \\
Undecided & 9 & 21 \\
Disagree & 3 & 7 \\
Strongly Disagree & 3 & 7 \\
TOTAL & 42 & 100 \\
The internal control system installed contributes to the operational \\
efficiency and effective management of this hospital \\
Strongly Agree & 21 & 50 \\
Agree & 12 & 29 \\
Undecided & 6 & 14 \\
Disagree & 3 & 7 \\
Strongly Disagree & - & - \\
TOTAL & 42 & 100 \\
The individual implementing internal control system determines its \\
success or otherwise. & & \\
Strongly Agree & 11 & 26 \\
Agree & 15 & 36 \\
Undecided & 6 & 14 \\
\hline & & \\
& &
\end{tabular}




\begin{tabular}{lll}
\hline Description & No of respondents & Percentage (\%) \\
\hline Disagree & 7 & 17 \\
Strongly Disagree & 3 & 7 \\
TOTAL & 42 & 100 \\
\hline
\end{tabular}

Source: Field Survey 2012

\subsection{Testing of Hypothesis}

Hypothesis is a testable proposition preferred by a researcher at the commencement of the research work which represents his or her beliefs or assumption about the relationship that exist within the research variables. It is an idea, suggestion put forward as a starting point for reasoning or expectation.

In order to validate some decisions arrived at in the analysis, it is necessary to test these results. The hypothesis will be tested using the chi-square given as:

$$
X^{2}=\frac{\Sigma(O-E)^{2}}{E}
$$

Where $\mathrm{X}^{2}=$ Chi-Square

$\mathrm{O}=$ Observed frequency and

$\sum=$ summation

$\mathrm{E}=$ Expected frequency.

The chi-square $(\mathrm{x})^{2}$ distribution depends on a quality referred to as the " degree of freedom" which is derived by applying $\mathrm{r}-1$ for a single row of r-cells and $(\mathrm{r}-1)(\mathrm{c}-1)$ for multiple rows and columns; where $r=$ numbers of rows and $c$ $=$ numbers of columns.

The result of the above calculation will be computed with $\mathrm{X}$ table value for the purpose of making decision either accepting or rejecting the hypothesis. The $\mathrm{X}$ table value is obtained as follows.

$\mathrm{X}^{2}$ tab where

$\mathrm{V}$ (the degree of freedom) $(\mathrm{R}-1)$ for single row of $\mathrm{r}$-cell

The level of significance to be used is 0.05 at $95 \%$ confidence level.

\section{Decision rule:}

In applying the chi-square technique, the following decision rules are used:

(1) If the chi-square calculated value $\left(\mathrm{x}^{2} \mathrm{c}\right)$ is greater than the tabulated value $\left(\mathrm{x}^{2} \mathrm{t}\right)$, then $\mathrm{H}_{0}$ should be rejected and $\mathrm{H}_{1}$ accepted.

(2) If the chi-square calculated value $\left(\mathrm{x}^{2} \mathrm{c}\right)$ is lesser than the chi-square tabulated value $\left(\mathrm{x}^{2} \mathrm{t}\right)$, then $\mathrm{H}_{0}$ should be accepted and $\mathrm{H}_{1}$ rejected.

\section{Testing of hypothesis $I$}

\section{Hypothesis I}

$\mathrm{H}_{0}$ Installation of internal control system has no significant effect on the performance of management of government parastatals.

$\mathrm{H}_{1}$ Installation of internal control system has a significant effect on the performance of management of government parastatals.

To test this hypothesis Question 10 will be used

$$
\mathrm{E}=\frac{\text { Total no observed }}{\text { No of rows }}=42 / 5=8.4
$$

Table 5. Testing of Hypothesis I

\begin{tabular}{llllll}
\hline Description & O & E & O-E & $(\mathbf{O - E})^{2}$ & $(\mathbf{O - E})^{\mathbf{2}} / \mathbf{E}$ \\
\hline Strongly Agree & 18 & 8.4 & 9.6 & 92.16 & 10.97 \\
Agree & 12 & 8.4 & 3.6 & 12.96 & 1.54 \\
Undecided & 8 & 8.4 & -0.4 & 0.16 & 0.02 \\
Disagree & 3 & 8.4 & -5.4 & 29.16 & 3.47 \\
Strongly Disagree & 1 & 8.4 & -7.4 & 54.76 & 6.52 \\
TOTAL & 42 & 42 & 0 & 189.2 & 22.54 \\
\hline
\end{tabular}

Degree of freedom $(\mathrm{df})=(\mathrm{r}-1)$

Where $r=$ number of rows $=5$

Therefore, degree of freedom $=(5-1)=4$

At 0.05 level of significance and 1 degree of freedom

Chi-square calculated value $\left(\mathrm{X}^{2} \mathrm{c}\right)=22.54$

Chi-square tabulated value $\left(\mathrm{X}^{2} \mathrm{t}\right)=9.49$

Decision rule: If $\mathrm{X}^{2} \mathrm{c}>\mathrm{X}^{2} \mathrm{t}$, accept $\mathrm{H}_{1}$ and reject $\mathrm{H}_{0}$

If $\mathrm{X}^{2} \mathrm{c}<\mathrm{X}^{2} \mathrm{t}$, accept $\mathrm{H}_{0}$ and reject $\mathrm{H}_{1}$

Since $X^{2} c$ (22.54.) is greater than $X^{2} t(9.49)$, we accept $H_{1}$ which states that the installation of internal control system has a significant effect on the performance of management of government parastatals.

\section{Hypothesis II}

$\mathrm{H}_{0}$ : Installation of internal control system has no significant effect on the growth and survival of government parastatals.

$\mathrm{H}_{1}$ : Installation of internal control system has a significant effect on the growth and survival of government parastatals.

To test this hypothesis Question 9 will be used

$$
\mathrm{E}=\frac{\text { Total no observed }}{\text { No of rows }}=42 / 8=8.4
$$

Table 6. Testing of Hypothesis II

\begin{tabular}{llllll}
\hline Description & O & $\mathbf{E}$ & O-E & $(\mathbf{O - E})^{\mathbf{2}}$ & $(\mathbf{O - E})^{\mathbf{2}} / \mathbf{E}$ \\
\hline Strongly Agree & 12 & 8.4 & 3.6 & 12.96 & 1.54 \\
Agree & 24 & 8.4 & 15.6 & 243.36 & 28.97 \\
Undecided & 3 & 8.4 & -5.4 & 29.16 & 3.47 \\
Disagree & 2 & 8.4 & -6.4 & 40.96 & 4.88 \\
Strongly Disagree & 1 & 8.4 & -7.4 & 54.76 & 6.52 \\
TOTAL & 42 & 42 & 0 & 354.96 & 45.38 \\
\hline
\end{tabular}

Degree of freedom $(\mathrm{df})=(\mathrm{r}-1)$

Where $\mathrm{r}=$ number of rows $=5$

Therefore, degree of freedom $=(5-1)=4$

At 0.05 level of significance and 1 degree of freedom

Chi-square calculated value $\left(\mathrm{X}^{2} \mathrm{c}\right)=45.38$

Chi-square tabulated value $\left(X^{2} t\right)=9.49$

Decision rule: If $\mathrm{X}^{2} \mathrm{c}>\mathrm{X}^{2} \mathrm{t}$, accept $\mathrm{H}_{1}$ and reject $\mathrm{H}_{0}$

If $\mathrm{X}^{2} \mathrm{c}<\mathrm{X}^{2} \mathrm{t}$, accept $\mathrm{H}_{0}$ and reject $\mathrm{H}_{1}$

Since $X^{2} c(45.38)$ is greater than $X^{2} t(9.49)$, we accept $H_{1}$ which states that the installation of internal control system has a significant effect on the growth and survival of government parastatals.

\section{Summary, Conclusions and Recommendations}

\subsection{Summary of Findings}

The purpose of this research work is to examine the Impact 
of Effective Internal Control in the Management of Mother and Child Hospital, Oke-Aro, Akure, Ondo State which is a government parastatal. In order to ensure successful conduct of this research work, the major source of information was obtained from the questionnaires that were distributed to the staff of Mother and Child Hospital Oke-Aro, Akure, Ondo State. Also, the use of materials such as the internet, textbooks, related lecture notes, papers, journals articles were consulted to gather useful information on the study and to achieve the objective of the study.

The hypotheses were tested using chi-square $\left(\mathrm{x}^{2}\right)$ statistical analysis method from which appropriate conclusions were drawn.

The result of the findings showed that an Internal Control System was instituted in Mother and Child Hospital, OkeAro, Akure, Ondo State and it had a great impact on the management, growth and survival of the hospital. It also showed that the internal control system put in place has assisted the management in achieving the organisation's objectives.

It was affirmed that the implementation of internal control system was the responsibility of everybody in the hospital. This is because virtually all employees produce information used in the internal control system and take actions that are needed to implement internal control.

\subsection{Conclusion}

The importance of effective internal control cannot be over-emphasized. It is a tool which is not just desirable in a large enterprise, but a necessary condition to her survival. If internal controls are sound it is more likely that the accounting records will be reliable and accurate. Effective internal control guarantees the success of an organization and also reduces the risk of failure.

Effective Internal control is a precautionary and preventive measure that must be in place to minimise or possibly eliminate fraud in government parastatals. It must be closely monitored and on regular basis be evaluated to determine whether or not, its implementation is in line with the set objectives.

Internal control or check does not exist separately on its own; everybody in the organization contributes his or her part to it. It is certain that there is no absolute standard of internal control. The circumstances and needs of business differ greatly that no two systems can work exactly alike. However, it suffices to state that an adequate system of internal control is the one that is economical and effective in respect of the resources, size and nature of the business. It is therefore obvious that no matter the size of the company, control is necessary.

Internal control is a continuous process which may change with time and event; hence the management should be active and pro-active to meet up with the changes in order to achieve its desired objectives.

\subsection{Recommendations}

The following recommendations are suggested for improving on the existing system:

- Adequate internal control should be maintained on the current system as well as strict adherence to management policies so as to ensure that the set objectives are achieved.

- The internal audit department/unit should be assessed regularly in order to ensure the effectiveness and efficiency of the accounting and internal control system and also to ensure that the risk of irregularities is minimized.

- In addition, internal check should be carried out to ensure that no one person is allowed to carry through and to record every aspect of a transaction so that without collusion between two or more persons, fraud is prevented and at the same time possibilities of errors are reduced to a minimum.

\section{References}

[1] Adeniyi, A. A. (2004). Auditing and Investigation (First Edition) Lagos: Value Analysis Consult Limited.

[2] Adewale, O. H. (2014). Internal Control System: A Managerial Tool for Proper Accountability. A Case Study of Nigerian Customs Service. European Scientific Journal, 10 (13), pp. 252-267.

[3] Ahiabor, G. and Mensah, Y. C. (2013). Effectiveness of Internal Control on the Finances of Churches in Greater Accra, Ghana. Research Journal of Finance and Accounting, 4 (13), pp. 115-120.

[4] Amudo, A. and Inanga, E. L. (2009). Evaluation of Internal Control Systems: A Case Study from Uganda. International Research Journal of Finance and Economics. pp. 3-6.

[5] Asika, N. (1991). Research Methodology in the behavioral science. Ikeja: Longman Nigeria Plc.

[6] ATSWA STUDY PACK Government Accounting Part II. Abuja FCT Nigeria: ABWA Publishers.

[7] City of Ashland (2009). Internal Controls Policy, June 2009, pp. 1-9.

[8] Committee of Sponsoring Organizations of the Treadway Commission (COSO, 2013): Internal Control- Integrated Framework, Executive Summary, May, 2013. Available at: https://na.theiia.org/standardsguidance/topics/Documents/Executive_Summaryz.pdf

[9] Gamage, C. T., Lock, K. L. and Fernando, A. (2014). Effectiveness of Internal Control System in State Commercial Banks in Sri Lanka. International Journal of Scientific Research and Innovative Technology, 1 (5), pp. 25-44.

[10] Kathleen, T. M. Internal Controls, a paper presented by: Assistant Vice President for Finance Indiana University (pp 3-4).

[11] Kelvin, B. (1999) Internal control and fraud prevention in hospital operations. New Delhi: Global Books \& Subscription services.

[12] Koech, D. C. and Thuo, M. G (2016). Factors Influencing Strategic Information Systems Implementation in Government Parastatals: A Case of Kenya Forest Service, Mau Forest Conservancy. European Scientific Journal, 12 (15), pp. 263-277. 
[13] Kuo-Tay, C. and Ronald, M. L. (1992) "Schematic Evaluation of Internal Accounting Control Systems". Erasmus University Rotterdam, The Netherlands.

[14] Malaysian Institute of Accountants: Internal auditing guidelines, last edited 05/02/2008.

[15] Millichamp, A. H. (2002). Auditing ( $8^{\text {th }}$ edition). Winchester, Hants: ELST publication.

[16] Montri, P., Sirisuthi, C. and Lammana, P. (2015). A study on components of internal control- based administrative system in secondary schools, Educational Research and Reviews, 10 (19), pp. 2617-2623, doi: 10.5897/ERR2015.2434.

[17] Nsanganzelu, A. J. and Jagero, N. (2011). The Levels of Factors that Contribute towards Efficiency, Effectiveness and Strength of the Internal Control Systems (ICSs) with Regard to Non-Current Assets Safeguard and Management in Public Institutions in Tanzania. International Journal of Academic Research in Business and Social Sciences, 1 (3), pp. 109-117.

[18] Ojo, O. (2005). Fundamentals of Research method. Lagos: Standard Publication.

[19] Olowookere, J. K. (2005). Fundamentals of Auditing (Third Edition) Ijebu-Ode: Triumph-Providential Publishers.

[20] Onyefulu, D. and Ofor, T. (2016) Effect of Internal Control on Fraud Prevention and Detection in the Public Sector in Nigeria. Journal of Accounting and Financial Management, 2 (4), pp. 21-27.

[21] Otto, R. (2014) Statement of Position: The Importance of Internal Controls, State of Minnesota, Office of the State Auditor, pp. 1-4.

[22] PWC (2012) State of the Internal Audit Profession Survey, March 2012. Pwc.com 2012-03-20. Retrieved 2013-09-04.
[23] Risk Assessment Portal. EPA. 13 May 2013. Retrieved 9 June 2013.

[24] Sawyer, Lawrence (2003). Sawyer's Internal Auditing, $5^{\text {th }}$ Edition, Institute of Internal Auditors. ISBN 97808941350095.

[25] Standard for internal Control in the Federal Government, United States General Accounting Office, Nov, 1999.

[26] Szabo, D. T. and Loccisano, A. E. (March 30, 2012) "POPs and Human Health.

[27] Taxmann's (2003), Auditing principles and practice (Second Edition) Taxmann, Allied Services (P.) Ltd.

[28] The Institute of Internal Auditors (2015). Definition of Internal Auditing. Available at: $\mathrm{http} / / / \mathrm{www}$.theiia.org/guidance/standards-andguidance/ippf/definition-of-internalauditing/?search $\% \mathrm{C} 2 \% \mathrm{BCdefinition.}$

[29] The Internal Control system: Reference framework Presentation of the work performed by The working group set up by the $A M F$, January 2007.

[30] The KPMG Review (1999) Internal Control: A Practical Guide. (pp. 25-27). Retrieved from www.ecgi.org/codes/documents/kpmg on Friday, 28th October, 2011. URL:

http//WWW.COSO.Org/publications/executivesummaryderiv ativeusage.html. https://www.nao.org.uk/wpcontent/uploads/2010/01/statement_internal_control.pdf Internal control - integrated framework published in the USA by the Committee of Sponsoring.

[31] World Council of Credit Unions (2002): Internal Control Requirement. Development Best Practices in credit union supervision (Pp 1). Retrieved from www.woccu.org on Friday, 28 October 2011. 